ISBN 978-93-84422-85-1

11th International Conference on Chemical, Agricultural, Biological and Environmental Sciences

(CABES-2018)

April 17-18, 2018 Kyoto (Japan)

\title{
Mangrove Forest as a Balancing Ecosystem and Source of Raw Materials of Mangrove Syrup in Raas Island, Indonesia
}

\author{
Rizal Kartika Wardhana ${ }^{1 *}$ and Vegi Alfindo Nantaris ${ }^{2}$ \\ Environmental Engineering Department, Islamic University of Indonesia, Yogyakarta, Indonesia
}

\begin{abstract}
Raas Island is one of the islands among the cluster of islands to the east of Madura Island. Raas Island has a total land area of 3.893 hectares and mangrove forest area of 779 hectares that located around Raas Island. The potential of this mangrove forest is very promising to the economic condition of Raas Island community as an additional income due to the main profession of the community as fishermen and farmers. There are many species of mangrove found in Raas Island, one of which is Sonneratia Alba (Pedada). This type of mangrove can be processed into mangrove syrup. Mangrove syrup contains a variety of vitamins that are diverse and good for human health. This has even received support from the District Office of Raas Islands. The SubDistrict even provides regulations on illegal logging of mangrove trees, so that people can be optimal in exploiting the potential of mangrove forests.
\end{abstract}

Keywords: Island, mangrove, pedada, syrup and economic

\section{Introduction}

The Republic of Indonesia is an archipelago consisting of 17.504 islands where there are 92 outermost small islands with 12 of them being the outermost point of national boundaries. As a country of origin, Indonesia has a wealth of natural resources, one of which is mangrove forest. Based on Indonesian Law No. 41/1999 on Forestry explains that mangrove is a forest ecosystem and therefore the government is responsible in management based on benefits and sustainability, community, justice, togetherness, openness, and integrity [1]

Mangrove has an important role both ecologically and economically. Ecologically, mangrove acts as a coastal protector of wind, waves and storms. Mangrove stands serve as a biological bastion of settlements, buildings and farms of strong winds or sea water intrusions. With high productivity, mangrove able to maintain the harmonization of the life cycle of various marine biota species because mangrove can serve as feeding, spawning and nursery ground for various types of marine and coastal biota. Economically, mangroves can be utilized directly for daily necessities such as firewood, building materials, household necessities, paper, medicines, bark and charcoal and even fruit can be processed into various foods and drinks [2].

Raas Island is one of the islands among the cluster of islands to the east of Madura Island. Raas Island has a total land area of 3.893 hectares and mangrove forest area of 779 hectares that located around Raas Island. The potential of this mangrove forest is very promising to the economic condition of Raas Island community as an additional income due to the main profession of the community as fishermen and farmers. Unfortunately, people in Raas Island have not glanced at the mangrove forest as a source of additional income.

In connection with the above, this study aims to exploit the potential of mangrove forests as an additional source of income Raas Island community. The use of mangrove fruit as a processed product that can be consumed and healthy for humans. Utilization through mangrove disposal will not affect the destruction of mangrove forest, so it is very good to do. It is expected that from this research people can process mangrove fruit as a source of income as well as a solution to overcome the threat of food insecurity in Indonesia. 


\section{Material and Method}

\subsection{Location}

The research was conducted in Brakas Village, Raas Subdistrict, Sumenep Regency, East Java Province (7008'47.38 "S 114034'15.63" E). The village area of Brakas is located east of Raas Island. The geographical position of the study site is presented on the map (Fig. 1).

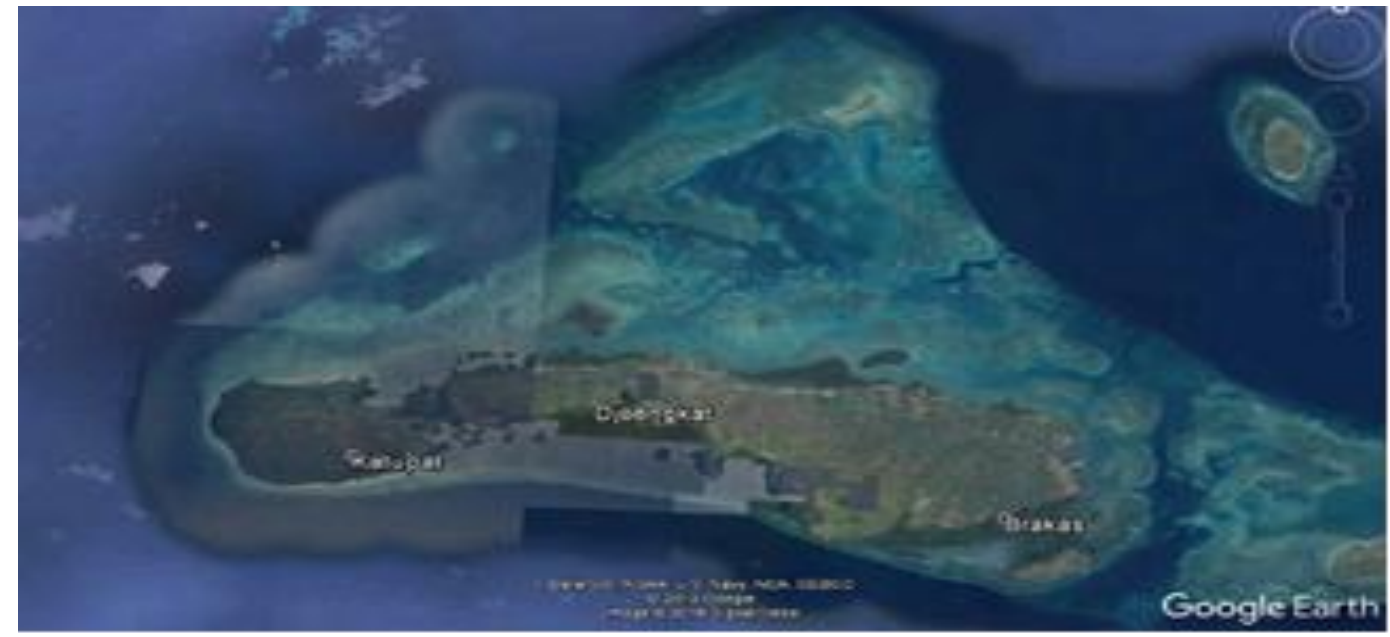

Fig. 1: Research location in Brakas Village, Raas Subdistrict, Sumenep Regency, East Java Province

\subsection{Method}

The method used in this research is survey method, that is a method which is done to conduct examination that takes place in field or research location. How the processing of mangrove fruit into food products as follows:

Phase of taking mangrove fruit: (i) Conducting observation to get initial information about the location to be used as research location, where researchers conducted observations in the field covering the entire area of mangrove forest about the physiognomy state of mangrove forest and tidal conditions in Brakas Village, Raas Sub-district, Sumenep Regency, East Java Province. (ii) Identify mangrove species directly in the field. (iii) The number of individuals of each mangrove species found is recorded.

Implementation phase. At first mangrove fruit type of pidada that has been ripe taken the fruit and then knead by hand to get the juice. After that, the juice is filtered and boiled until boiling by adding water, sugar, rosella, and cinnamon to get a fresh taste with an attractive color.

\subsection{Analysis}

The data obtained were analyzed using qualitative descriptive analysis.

\section{Result and Discussion}

\subsection{Community Perception Against Mangrove Forest Potency}

Raas Island is one of the islands among the cluster of islands in the east of Madura Island. Raas Island has an area of 3.893 hectares and a mangrove forest area of 779 hectares that located in the vicinity of Raas Island. The potential of this mangrove forest is very promising for the economic condition of Raas Island community as an additional income because it becomes the main profession of the community as fishermen and farmers. Unfortunately, people on Raas Island have not seen mangrove forests as a source of additional income.

The coastal areas of Braka Village, Raas Subdistrict, Sumenep Regency, East Java Province and the entire island of Raas have various natural resources potential as well as local wisdom that supports the conservation of mangrove forest ecosystems. The mangrove forest is well managed by the community. Mangrove fruit is 
actually widely used by the community as a flour but only in small scale as a substitute for food in case of food staple crisis.

Utilization of mangrove fruit as syrup is still not known to the local community, this is due to lack of understanding about the processing of mangrove fruit by the community. In addition, it can be processed into flour and syrup, mangrove fruit can also be processed into other diverse food products and also healthy. There are food and beverage products based on mangrove fruit, so that mangrove fruit can be a source of alternative raw materials for local communities and in Indonesia.

From the results of observations and interviews with government of Raas Island until the community obtained the result that the community support and enthusiastic in processing the mangrove fruit into syrup. Subdistrict even provides regulations on illegal logging of mangrove trees, so that people can be optimal in exploiting the potential of mangrove forests.

\subsection{Mangrove Syrup}

There are many species of mangrove found in Raas Island, one of which is Sonneratia Alba (Pedada). Sonneratia Alba (Pedada) has around and paired leaves on its branch, about $7 \mathrm{~cm}$ long, at the end of the leaf slightly curved downward. S.alba has white flowers. The fruit is $4 \mathrm{~cm}$ in size and is green with a star-like and hard shape. The bark is gray to brown with a slightly cracked texture. Rooting of pneumatic root for respiration. This type of mangrove can be processed into mangrove syrup. This fruit can also be processed into a healthy and safe mangrove syrup for humans.

According to Ruth Dwi Elsa Manalu (2011) about the amount of Vitamin in Pedada Fruit (Sonneratia Caseolaris) and its Processed Results calculated on the dry basis that the pedada fruit has an average diameter of $6.05 \mathrm{~cm}$ and an average weight of $52.15 \mathrm{~g}$. Pedada has a water content of $84.76 \%$, ash $8.40 \%, 4.82 \%$ fat, $9.21 \%$ protein, and carbohydrates $77.57 \%$. Proximate level after treatment ie syrup with water content $57,81 \%$, ash $0,41 \%$, fat 1,63\%, protein 0,23\%, and carbohydrate 97,58\%. Level of vitamin A fruit pedada $221.97 \mathrm{IU} / 100 \mathrm{~g}$ and $12.77 \mathrm{IU} / 100 \mathrm{~g}$ pedada syrup. Vitamin B1 levels of pedada fruit are $5.04 \mathrm{mg} / 100 \mathrm{~g}$, and pedillary syrup $6.72 \mathrm{mg} / 100 \mathrm{~g}$. Vitamin B2 content of pedada fruit that is $7.65 \mathrm{mg} / 100 \mathrm{~g}$, and pedal syrup $1.12 \mathrm{mg} / 100 \mathrm{~g}$. Vitamin C content of pedada fruit is $56,74 \mathrm{mg} / 100 \mathrm{~g}$ and syrup of $17.08 \mathrm{mg} / 100 \mathrm{~g}$. The content of vitamin C is high enough to treat thrush, chapped lips, and heat in [3].

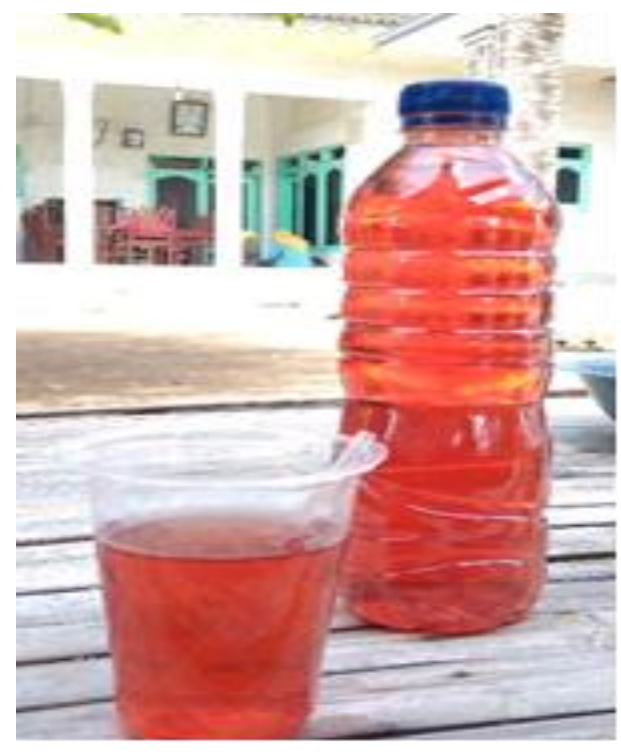

Fig. 2: Mangrove Syrup

Mangrove syrup contains a variety of vitamins that are diverse and good for human health. Therefore, support is required by local government and community participation in increasing mangrove syrup production. 
Increased production of mangrove syrup is expected to become a commodity of Raas Island as well as a source of economic improvement of the community.

\section{Conclusion}

From the results of the above description can be concluded that the utilization of mangrove waste into syrup can be one of the superior commodities of Raas Island as well as a source of economic improvement of society. It even got support from the Raas Island District Service. Sub-districts even provide regulations on illegal logging of mangrove trees, so that people can be optimal in exploiting the potential of mangrove forests.

\section{References}

[1] Halidah. 2008. Mangrove Forest Function for Coastal Welfare. Forestry Journal, Gadjah Mada University: Yogyakarta.

[2] Siti Khoiriah. 2015. Financial Analysis of Small and Medium Enterprises Mangrove Syrup in the District of West Rangsang District of Meranti Islands. Journal of Economics, Faculty of Teacher Training and Education University of Riau: Riau.

[3] Ruth Dwi Elsa. 2011. Levels of Some Vitamins in Pedada Fruit (Sonneratia Caseolaris) and Processed Products. Journal of Department of Aquatic Product Technology, Faculty of Fisheries and Marine Sciences: Bogor. 